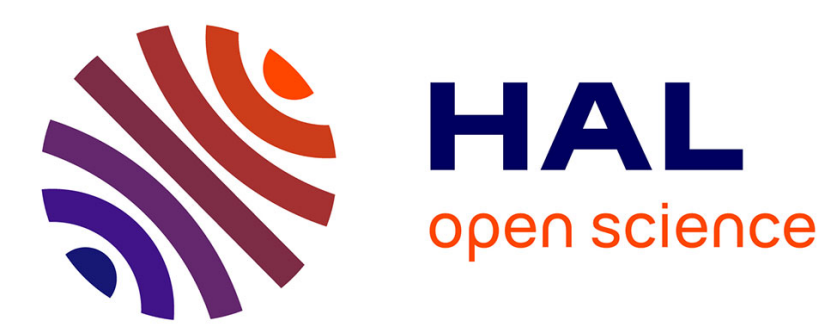

\title{
Mullite interaction with bismuth oxide from minerals and sol-gel processes
}

Fayza Gridi-Bennadji, J. Zimova, Jean-Paul Laval, Philippe Blanchart

\section{To cite this version:}

Fayza Gridi-Bennadji, J. Zimova, Jean-Paul Laval, Philippe Blanchart. Mullite interaction with bismuth oxide from minerals and sol-gel processes. 10th European International Conference of the European Ceramic Society, Jun 2007, Berlin, Germany. pp.417-422. hal-00282095

\section{HAL Id: hal-00282095 \\ https://hal.science/hal-00282095}

Submitted on 26 May 2008

HAL is a multi-disciplinary open access archive for the deposit and dissemination of scientific research documents, whether they are published or not. The documents may come from teaching and research institutions in France or abroad, or from public or private research centers.
L'archive ouverte pluridisciplinaire HAL, est destinée au dépôt et à la diffusion de documents scientifiques de niveau recherche, publiés ou non, émanant des établissements d'enseignement et de recherche français ou étrangers, des laboratoires publics ou privés. 


\title{
Mullite interaction with bismuth oxide from minerals and sol-gel processes
}

\author{
F. Gridi-Bennadji *, J. Zimová ${ }^{* *}$, J. P. Laval ${ }^{* * *}$, P. Blanchart * \\ ${ }^{(*)}$ GEMH - ENSCI, Limoges, France \\ ${ }^{(* *)}$ ICT PRAGUE, Czech Rep. \\ ${ }^{(* * *)}$ SPCTS, Limoges, France
}

\begin{abstract}
The high temperature treatment of kaolinite-muscovite alternate layers doped by bismuth oxide was studied by TGA and DTA, $\mathrm{X}$ ray diffraction, and electron microscopy (SEM). Thermal analyses shows that the two main transformation stages are the dehydroxylation of phyllosilicates and the structural reorganization of the whole assembly. During dehydroxylation, a progressive decrease of the structural order of kaolinite and muscovite occurs. It is more significant at temperature above $1000^{\circ} \mathrm{C}$ and mullite, glass and Alrich oxides are formed. Mullite exhibits an accentuated acicular morphology along 3 preferential orientations in relation to the remaining structure in the basal $(001)_{\text {musc }}$ planes of the former muscovite. With addition of bismuth oxide, SEM observations point to the strong accentuation of mullite growth along the c axis, at the very low temperature of $1050^{\circ} \mathrm{C}$. This behavior was studied with various mullite-bismuth oxide compounds at temperatures ranging from $1000^{\circ} \mathrm{C}$ to $1400^{\circ} \mathrm{C}$. Solgel processing were performed with TEOS $\left(\mathrm{C}_{2} \mathrm{H}_{5} \mathrm{O}\right)_{4} \mathrm{Si}$, aluminum nitrate $\mathrm{Al}\left(\mathrm{NO}_{3}\right)_{3} \cdot 9 \mathrm{H}_{2} \mathrm{O}$ and bismuth nitrate $\mathrm{Bi}\left(\mathrm{NO}_{3}\right)_{3}$. From Rietveld refinements of $\mathrm{X}$ ray diffraction patterns it was found that bismuth doesn't form a specific phase with mullite during the mullite nucleation and growth. At low $\mathrm{Bi}_{2} \mathrm{O}_{3}$ content, mullite coexists with amorphous silico-aluminate phases, even at high temperature. When the $\mathrm{Bi}_{2} \mathrm{O}_{3}$ content increases above $12 \mathrm{~mol} \%$, mullite is no longer crystallized. Above $750^{\circ} \mathrm{C}$, aluminum bismuth oxide coexists with silicon bismuth oxide. The liquidus temperature is below $1100^{\circ} \mathrm{C}$ and decreases with $\mathrm{Bi}_{2} \mathrm{O}_{3}$ additions. Above the liquidus, only corundum and a liquid coexist. A tentative mullite- $\mathrm{Bi}_{2} \mathrm{O}_{3}$ binary phase diagram is then proposed. These results evidence the $\mathrm{Bi}_{2} \mathrm{O}_{3}$ role on the early and large mullite growth in kaolinite-muscovite materials. Particularly, a very low quantity of a low viscous phase favor the local mobility of diffusing species and promotes the nucleation and growth of very large mullite crystals. In this way, highly textured and dense ceramics are obtained at low sintering temperature. Thin substrates $(<500 \mu \mathrm{m})$ present specific mechanical behaviors with the deviation of cracks along mullite layers.
\end{abstract}

Keywords: Muscovite, Kaolinite, Mullite, $\mathrm{Bi}_{2} \mathrm{O}_{3}$.

*Corresponding author : p_blanchart@ensci.fr

\section{Introduction}

Mullite is an important high-technology ceramics for high temperature applications [1]. The addition of cations in the reaction mixture of mullite allows the improvement of the physical properties of sintered materials. $\mathrm{Ca}^{2+}$ or $\mathrm{Ba}^{2+}$ can added [2], but the addition of $\mathrm{Bi}^{3+}$ appears to be a promising way for mullite formation in compositions. It was also observed the effects of some oxides $\left(\mathrm{SnO}_{2}, \mathrm{SbO}_{2}\right)$ in the phase formation and the microstructural evolution of mullite ceramics [3]. In general, $\mathrm{Bi}_{2} \mathrm{O}_{3}$ doping have a much better effects on densification than $\mathrm{SnO}_{2}$ and $\mathrm{Sb}_{2} \mathrm{O}_{3}$, whereas the latter is an effective additive to decrease the temperature of mullite phase formation in diphasic gels. The addition of other oxides which form a solid solution with mullite such as $\mathrm{Fe}_{2} \mathrm{O}_{3}$ or $\mathrm{TiO}_{2}$ induces the increase of both the unit cell volume and of the crystallite size, when they are added in large proportion (up to $10 \mathrm{~mol} \%$ ). In the case of $\mathrm{Fe}_{2} \mathrm{O}_{3}$, it leads to the decrease of the crystallization temperature $\left(\sim 200^{\circ} \mathrm{C}\right)$. Simultaneously the crystal morphology is also changed from parallelepipedic to acicular [4].

In mullite ceramics, some additives were considered to reduce the viscosity of the $\mathrm{SiO}_{2}$-rich liquid phase, favoring a higher mobility of the diffusing species. The dissolution of $\mathrm{Al}_{2} \mathrm{O}_{3}$ species into the $\mathrm{SiO}_{2}$-rich liquid phase controls the rate of the mullite formation [5]. Also, the aluminum compounds might act as nuclei for crystallization of mullite crystal and the mullite formation temperature is significantly decreased.

The aim of the study is to determine the phase formation against temperature, from mullite-bismuth oxide compounds, which are synthesized using diphasic gels. The role of existing liquid phases is observed in the case of mullite crystallization in muscovite-kaolinite compounds.

\section{Experimental}

Mullite powders are usually prepared by methods such as co-precipitation using salts [2], sol-gel [1,6] and spray pyrolysis [7-9]. In this study, mullite compositions were synthesized with sol-gels using TEOS $\left(\mathrm{C}_{2} \mathrm{H}_{5} \mathrm{O}\right)_{4} \mathrm{Si}$, aluminum nitrate $\mathrm{Al}\left(\mathrm{NO}_{3}\right)_{3} \cdot 9 \mathrm{H}_{2} \mathrm{O}$ and bismuth nitrate $\mathrm{Bi}\left(\mathrm{NO}_{3}\right)_{3}$. Aluminum nitrate and bismuth nitrate were dissolved in aqueous solution of nitrite acid. TEOS was diluted in ethanol. Solutions were subsequently mixed at $60^{\circ} \mathrm{C}$ and become gel after 
4 days. Gels were dried at $110^{\circ} \mathrm{C}$ for 24 hour. In table I the stoechiometry of used compounds are presented and reported in the ternary diagram $\mathrm{SiO}_{2}-\mathrm{Al}_{2} \mathrm{O}_{3}-\mathrm{Bi}_{2} \mathrm{O}_{3}$ in figure 1 [10-12]. All compositions are along and beside the pseudo-binary mullite-bismuth oxide.

\begin{tabular}{|c|c|c|}
\hline ref & Stoechiometry & $\begin{array}{c}\mathrm{Bi}_{2} \mathrm{O}_{3} \\
\mathrm{wt} \%-\mathrm{mol} \%\end{array}$ \\
\hline 1 & $3 \mathrm{Al}_{2} \mathrm{O}_{3} \cdot 2 \mathrm{SiO}_{2}$ & $0-0$ \\
\hline 2 & $\left.3 \mathrm{Al}_{2} \mathrm{O}_{3} \cdot 2\left(\mathrm{Si}_{0,84} \cdot \mathrm{Bi}_{0,16}\right) \mathrm{O}_{2}\right)$ & $15-19$ \\
\hline 3 & $3\left(\mathrm{Al}_{1,8} \cdot \mathrm{Bi}_{0,2}\right) \mathrm{O}_{3} \cdot 2 \mathrm{SiO}_{2}$ & $26-33$ \\
\hline 4 & $\left.3 \mathrm{Al}_{2} \mathrm{O}_{3} \cdot 2\left(\mathrm{Si}_{0,7} \cdot \mathrm{Bi}_{0,3}\right) \mathrm{O}_{2}\right)$ & $26-42$ \\
\hline 5 & $\begin{array}{c}3 \mathrm{Al}_{2} \mathrm{O}_{3} \cdot 2 \mathrm{SiO}_{2}+ \\
5 \mathrm{~mol}_{2} \mathrm{Bi}_{2} \mathrm{O}_{3}\end{array}$ & $5.2-5$ \\
\hline 6 & $\begin{array}{c}3 \mathrm{Al}_{2} \mathrm{O}_{3} \cdot 2 \mathrm{SiO}_{2}+ \\
20 \mathrm{~mol}_{2} \mathrm{Bi}_{2} \mathrm{O}_{3}\end{array}$ & $18-20$ \\
\hline 7 & $\begin{array}{c}3 \mathrm{Al}_{2} \mathrm{O}_{3} \cdot 2 \mathrm{SiO}_{2}+ \\
40 \mathrm{~mol}_{2} \mathrm{Bi}_{2} \mathrm{O}_{3}\end{array}$ & $30-40$ \\
\hline
\end{tabular}

Tab. I : Compositions of mullite compounds

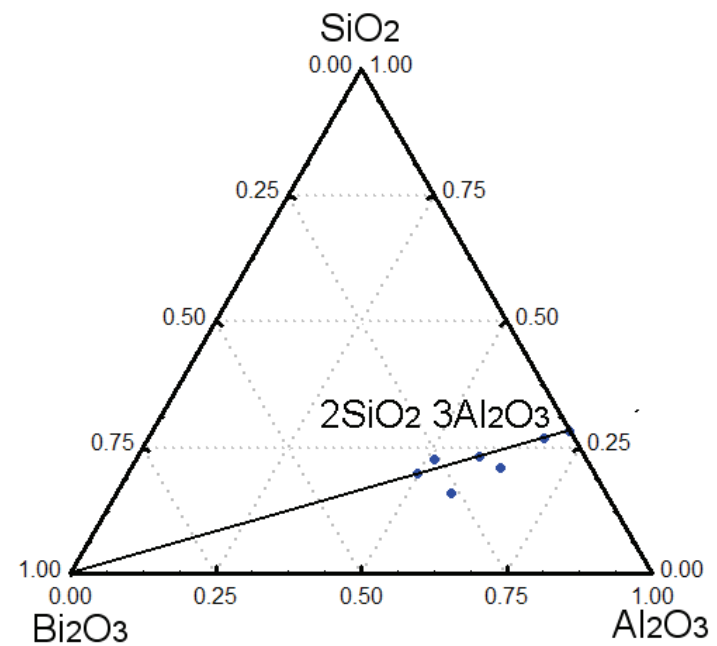

Fig. 1: Compositional area (wt $\%)$ in the ternary diagram $\mathrm{SiO}_{2}-\mathrm{Al}_{2} \mathrm{O}_{3}-\mathrm{Bi}_{2} \mathrm{O}_{3}$

X-ray diffractions were performed with a D5000 (Bruker) and pattern refinements were obtained by the Rietveld method, using the FullProf software. The thermal behavior of gels after calcinations at different temperatures up to $1100^{\circ} \mathrm{C}$ were studied by DTA (Setsys, SETARAM) under air atmosphere at a constant heating rate of $10^{\circ} \mathrm{C} \mathrm{min}^{-1}$. Curve backgrounds were corrected by preliminary experiments with $\alpha$ alumina.

\section{Results and discussion}

\section{DTA study}

Differential thermal analysis (DTA) of mullite gel exhibits typical endothermic peaks at $550-650^{\circ} \mathrm{C}$, due to the loss of hydroxyls and an exothermic peak at $\sim 980^{\circ} \mathrm{C}$ related to the crystallization of Al-Si spinel. A second weak exothermic peak at $\sim 1250^{\circ} \mathrm{C}$ corresponds to a secondary mullitization process and cristobalite crystallization $[13,14]$.

DTA of samples containing bismuth $(4,5,6$ and 7 in table I), were performed after heating at $500^{\circ} \mathrm{C}$ to preliminary remove all volatile species. The DTA curve of sample 4 in figure 2 presents four exothermal peaks at $530,892,958$ and at $1044^{\circ} \mathrm{C}$.

With sample 5, the DTA curve in figure 2 indicates four exothermal peaks at $530,905,971{ }^{\circ} \mathrm{C}$ and one weak peak between 1000 and $1100^{\circ} \mathrm{C}$. DTA curve of sample 4 differs to that of sample 5 in the intensity of the two main exothermic peaks. With sample 5 the crystallization process is slightly more accentuated and occurs at a higher temperature.

The sample 6 in figure 2 exhibits three DTA exothermal peaks at 526,885 and $1210^{\circ} \mathrm{C}$ and one small endothermic peak at $730^{\circ} \mathrm{C}$.

In the case of sample containing 7 , the DTA curve (figure 2) shows two endothermic peaks at $725^{\circ} \mathrm{C}$ and $875^{\circ} \mathrm{C}$ and two exothermal peaks at $815^{\circ} \mathrm{C}$ and $1293^{\circ} \mathrm{C}$. In this sample with the highest bismuth content, some peaks should be related to the transition of monoclinic $\alpha$-phase) $\rightarrow \delta$ (fcc-face central cubic) of bismuth oxide, which occurs at $705-1013^{\circ} \mathrm{C}$. The wide variation of the transition temperature is related to the purity of samples. The melting point of $\mathrm{Bi}_{2} \mathrm{O}_{3}$ is at $840^{\circ} \mathrm{C}$ [15].

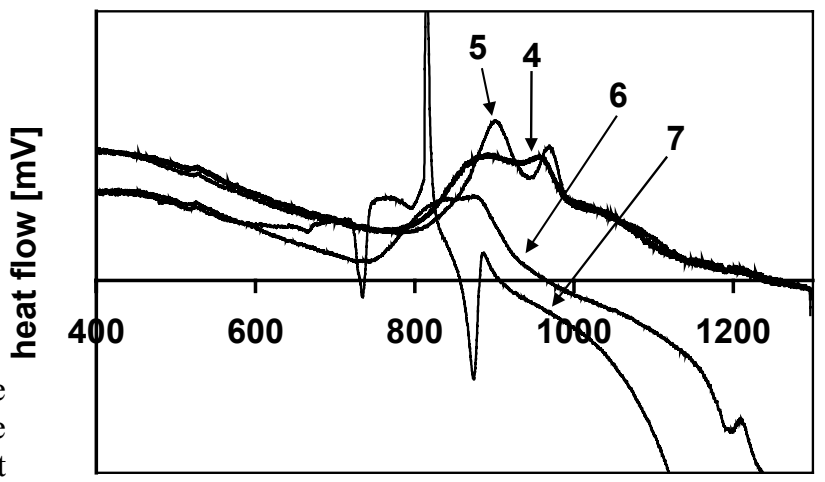

temperature $\left[{ }^{\circ} \mathrm{C}\right]$

Fig. 2: DTA curve of samples 4, 5, 6 and 7.

Whereas pure mullite (sample 1) presents a typical exothermic peak at $980^{\circ} \mathrm{C}$, mullite with more than 5 mol.\% bismuth exhibit a more complex behavior. The comparison of curves from sample $4 \quad\left(3 \mathrm{Al}_{2} \mathrm{O}_{3}\right.$. $\left.2\left(\mathrm{Si}_{0,7} \cdot \mathrm{Bi}_{0,3}\right) \mathrm{O}_{2}\right)$ and from sample 5 (5mol.\% bismuth) shows a significant difference in intensity of the two main peaks. With sample 6 (20 mol.\% bismuth), we observe a smoother variation, in comparison with curve variations of other samples. The weak peaks at $730^{\circ} \mathrm{C}$ and at $885^{\circ} \mathrm{C}$ are probably related to the transition of 
bismuth oxide. In sample 7 (40 mol.\% bismuth), we observe three peaks, which are originated from transitions of bismuth oxide $\left(735^{\circ} \mathrm{C}, 815^{\circ} \mathrm{C}\right.$ and $875^{\circ} \mathrm{C}$ ). The high temperature peaks at $1210^{\circ} \mathrm{C}$ for mullite with $20 \mathrm{~mol} . \% \mathrm{Bi}$ and at $1193^{\circ} \mathrm{C}$ in mullite with $40 \mathrm{~mol} . \% \mathrm{Bi}$ are due to the structural transformation of Al-Si spinel to new phases. In general, the curve slope at high temperature increases with the bismuth content.

\section{$\mathrm{X}$ ray experiments}

In a first approach, dried gels of samples 1, 2 and 3 were heated at $1350^{\circ} \mathrm{C}$ for 3 hours before XRD measurements. The Rietveld method was used to determine the mullite structural characteristics with bismuth additions in initial compositions.

In general, the orthorhombic mullite structure and the stoechiometry $3 \mathrm{Al}_{2} \mathrm{O}_{3} \quad 2 \mathrm{SiO}_{2}$ are always obtained. When the bismuth content increases. But a significant background variation is observed from an increasing content of liquid phase.

For a better understanding of transformations with temperature, X-ray diffractometry was used with heated samples 4, 5, 6 and 7, at typical temperatures near the onset and end of peaks in DTA curves of figure 2. All thermal cycles with a 30 min holding time were followed by a quenching stage to retain a steady state of phases. Temperature values for samples are reported in table II.

\begin{tabular}{|c|c|}
\hline Sample & Temperature \\
\hline 4 & $1000^{\circ} \mathrm{C}, 1100^{\circ} \mathrm{C}$ \\
\hline 5 & $1000^{\circ} \mathrm{C}, 1100^{\circ} \mathrm{C}$ \\
\hline 6 & $1000^{\circ} \mathrm{C}, 1100^{\circ} \mathrm{C}, 1250^{\circ} \mathrm{C}$ \\
\hline 7 & $770^{\circ} \mathrm{C}, 845^{\circ} \mathrm{C}, 930^{\circ} \mathrm{C}, 1200^{\circ} \mathrm{C}$ \\
\hline
\end{tabular}

Tab. II : Quenching temperatures of samples 4, 5, 6, 7

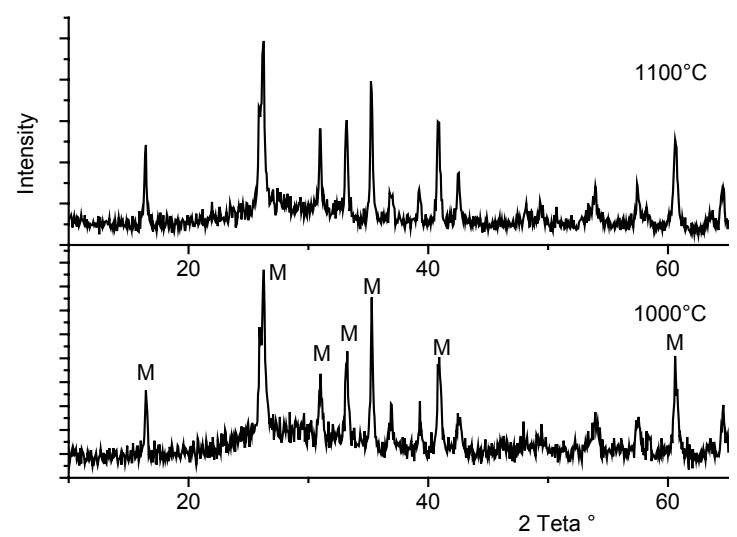

Fig. 3 : X-ray patterns of sample 4 heated at $1000^{\circ} \mathrm{C}$ and $1100^{\circ} \mathrm{C}$

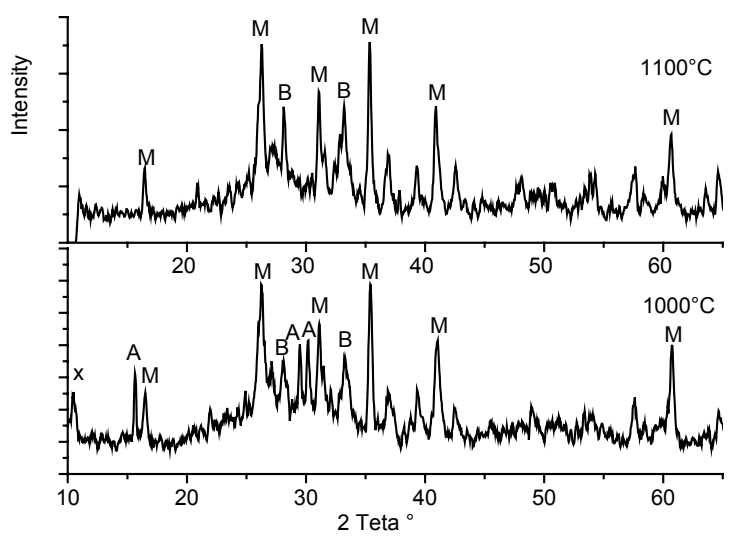

Fig. 4 : X-ray diffractogrammes for sample $5\left(3 \mathrm{Al}_{2} \mathrm{O}_{3}\right.$. $\left.2\left(\mathrm{Si}_{0,7} \cdot \mathrm{Bi}_{0,3}\right) \mathrm{O}_{2}\right)$ calcined at 1000 and $1100^{\circ} \mathrm{C}$; $(\mathrm{M}-$ mullite, A-aluminum bismuth oxide, B-bismuth silicon oxide).

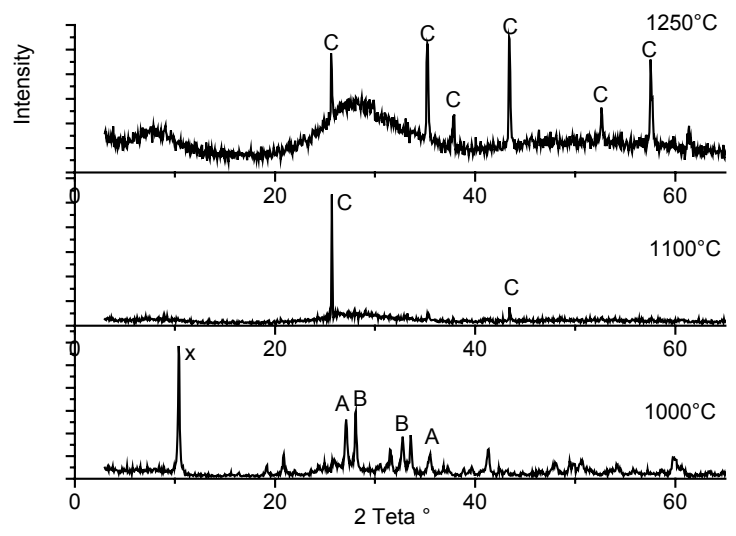

Fig. 5 : X-ray patterns of sample 6 mullite with $18 \mathrm{wt} . \%$ $\mathrm{Bi}_{2} \mathrm{O}_{3}$, heated at $1000^{\circ} \mathrm{C}, 1100^{\circ} \mathrm{C}$ and $1250^{\circ} \mathrm{C}$. C: corundum.

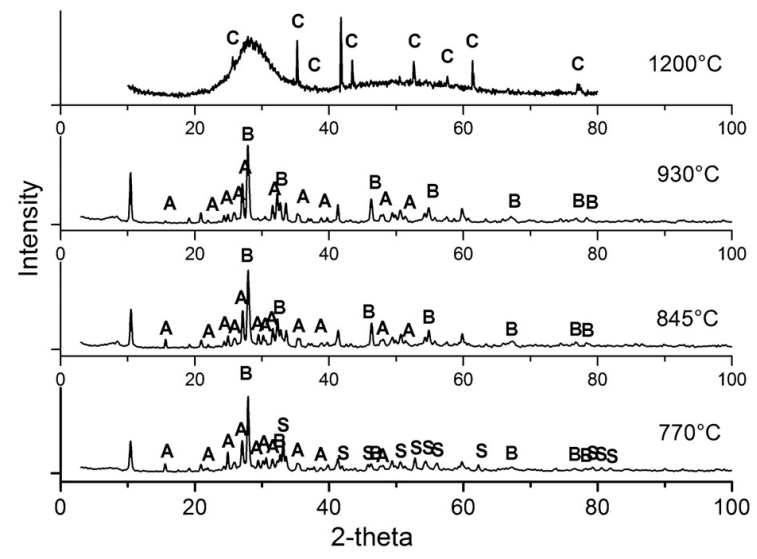

Fig. 6 : X-ray patterns of sample 7 mullite with 40wt.\% $\mathrm{Bi}_{2} \mathrm{O}_{3}$, heated in the $770-1250^{\circ} \mathrm{C}$ temperature range.

$\mathrm{C}$ : corundum.

Patterns of sample 5, containing $5 \mathrm{wt} \%$ of $\mathrm{Bi}_{2} \mathrm{O}_{3}$ and heated at $1000^{\circ} \mathrm{C}$ and $1100^{\circ} \mathrm{C}$ are in figure 3 . It is seen 
that only orthorhombic mullite with the stoechiometry $3 \mathrm{Al}_{2} \mathrm{O}_{3} 2 \mathrm{SiO}_{2}$ is identified.

Figure 4 shows $\mathrm{X}$-ray patterns of sample 4 containing $26 \mathrm{wt} \%$ of $\mathrm{Bi}_{2} \mathrm{O}_{3} \quad\left(3 \mathrm{Al}_{2} \mathrm{O}_{3} 2\left(\mathrm{Si}_{0,7} \cdot \mathrm{Bi}_{0,3}\right) \mathrm{O}_{2}\right)$ heated at $1000^{\circ} \mathrm{C}$ and $1100^{\circ} \mathrm{C}$. At $1100^{\circ} \mathrm{C}$, peaks from mullite, aluminum bismuth oxide and aluminium bismuth oxide are clearly recognized. Identified phases are orthorhombic mullite $\mathrm{Al}_{2}\left(\mathrm{Al}_{2.8} \mathrm{Si}_{1.2}\right) \mathrm{O}_{9.54}$ (pattern 01084-1205), cubic bismuth silicon oxide $\mathrm{Bi}_{12} \mathrm{Si}_{0.87} \mathrm{O}_{20}$ (pattern 01-084-0090) and aluminium bismuth oxide $\mathrm{Al}_{4} \mathrm{Bi}_{2} \mathrm{O}_{9}$ (pattern 00-025-1048). At $1100^{\circ} \mathrm{C}$, peaks from sample 4 indicate that aluminum bismuth oxide vanishes and that the relative content of bismuth silicon oxide increases in comparison to that of mullite.

For both patterns the large variation of the background indicate the presence of an amorphous phase or a liquid. Correspondingly, the smooth endothermic variation in the DTA curve of figure 2 above $958^{\circ} \mathrm{C}$ should be related to the liquid formation.

In figure 5, sample 6 with $18 \mathrm{wt} . \%$ bismuth heated at $1000^{\circ} \mathrm{C}$ has peaks from bismuth silicon oxide and aluminum silicon oxide. But a new phase is evidenced with a major peak at 10.442 teta $^{\circ}$. This new phase also occurs in sample 4 at $1000^{\circ} \mathrm{C}$ and in all samples containing more than $5 \mathrm{wt} \%$, below $1100^{\circ} \mathrm{C}$. The stoechiometry of this phase is supposed to be similar to a Aluminium Silicon Bismuth oxide, but further work are necessary to precise the structural characteristics. At the $1000^{\circ} \mathrm{C}$ temperature, the background variation indicates the occurrence of a liquid, in accordance to the DTA curve, which shows a significant endothermic variation at $885^{\circ} \mathrm{C}$.

At $1100^{\circ} \mathrm{C}$ and $1250^{\circ} \mathrm{C}$, sample 6 show the progressive formation of sharp peaks from a single phase, very similar to corundum (pattern 00-010-0173). Structural characteristics of this phase were identified after heating at $1200^{\circ} \mathrm{C}$ for 14 hours holding time and sampling a single crystal. The obtained structural parameters are the following: system hexagonal (rhomboedric, R-3C or R3C); $\mathrm{a}=4,735 \AA ; \mathrm{b}=4,735$ $\AA ; \mathrm{c}=12,941 \AA ; \alpha=90^{\circ} ; \beta=90^{\circ} ; \gamma=120^{\circ}$. These data are close to that of corundum $\left(\alpha-\mathrm{Al}_{2} \mathrm{O}_{3}\right)$.

For a higher $\mathrm{Bi}_{2} \mathrm{O}_{3}$ content (figure 6), sample 7 with $30 \mathrm{wt} \% \mathrm{Bi}_{2} \mathrm{O}_{3}$ heated at $770^{\circ} \mathrm{C}$ has peaks from bismuth silicon oxide, aluminum silicon oxide and bismuth silicate (sillenite $\mathrm{Bi}_{12} \mathrm{SiO}_{20}$, pattern 00-037-085). After hating at $845^{\circ} \mathrm{C}$ and $930^{\circ} \mathrm{C}$, peaks from sillenite vanished and peaks from bismuth silicon oxide and aluminum bismuth oxide are present. At $1200^{\circ} \mathrm{C}$, peaks from the same phase already observed in sample 6 , are very similar to corundum peaks.

The major peak at $10.44^{\circ}$ teta is also observed at $770^{\circ} \mathrm{C}, 845^{\circ} \mathrm{C}$ and $930^{\circ} \mathrm{C}$, as in samples 6 . It must be precisely identified in a future work. From these experiments, we note the occurrence of a liquid at temperatures above $930^{\circ} \mathrm{C}$ that corresponds to the strong endothermic variation in the DTA curve of figure 2 .
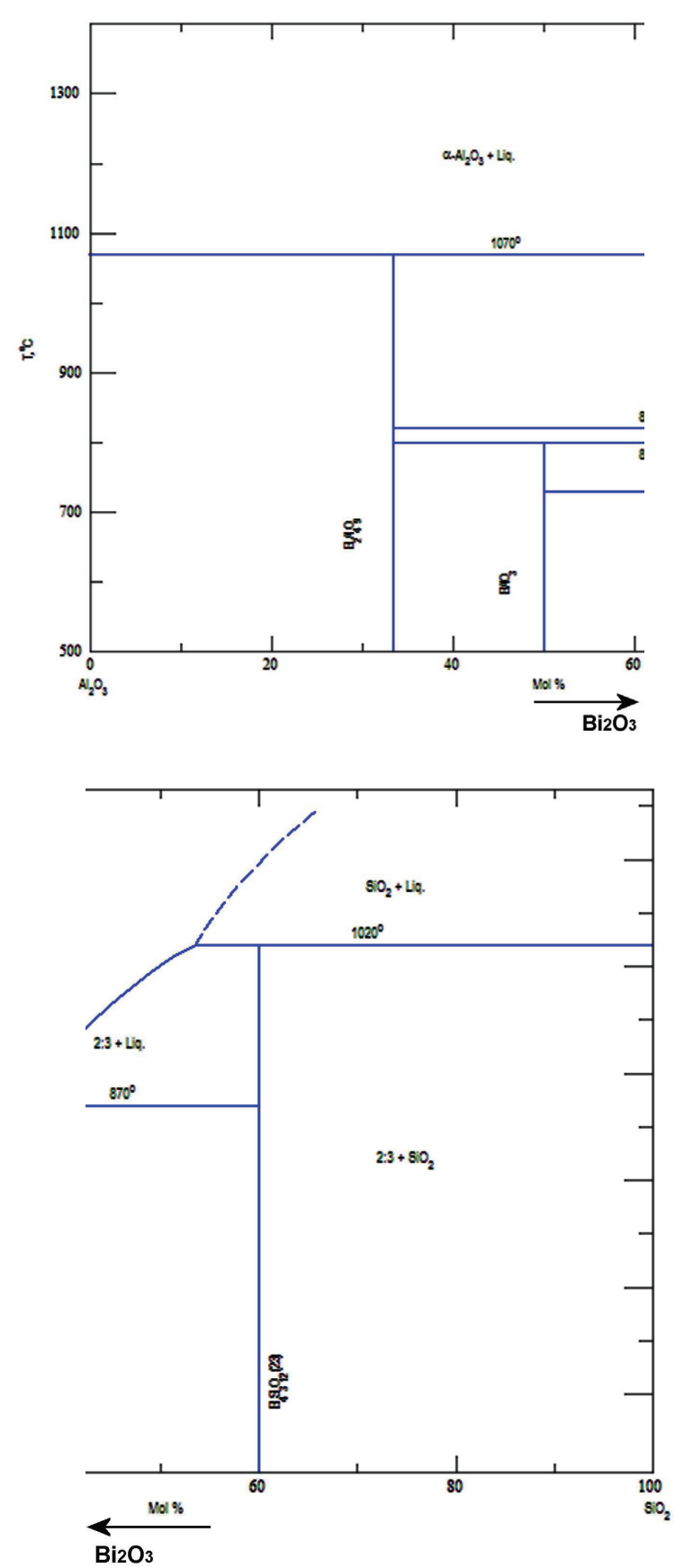

Fig. 7 : binary diagrams in the system $\mathrm{SiO}_{2}-\mathrm{Al}_{2} \mathrm{O}_{3}-$ $\mathrm{Bi}_{2} \mathrm{O}_{3}$.

\section{Three-phases diagram}

A literature review reveals the lack of information about the $\mathrm{SiO}_{2}-\mathrm{Al}_{2} \mathrm{O}_{3}-\mathrm{Bi}_{2} \mathrm{O}_{3}$ ternary system. Only two-phase diagrams are reported: $\mathrm{Al}_{2} \mathrm{O}_{3}-\mathrm{SiO}_{2}$ [11], $\mathrm{Al}_{2} \mathrm{O}_{3}-\mathrm{Bi}_{2} \mathrm{O}_{3}$ [10], $\mathrm{Bi}_{2} \mathrm{O}_{3}-\mathrm{SiO}_{2}$ [12]. The $\mathrm{Al}_{2} \mathrm{O}_{3}$ and $\mathrm{SiO}_{2}$ rich regions of two binary diagrams are in figure 7 a-b respectively. We observe in the $\mathrm{Al}_{2} \mathrm{O}_{3}-\mathrm{SiO}_{2}$ system the presence of the $\mathrm{Al}_{4} \mathrm{Bi}_{2} \mathrm{O}_{9}$ phase which was observed in compositions 6 and 7 containing 20$40 \mathrm{~mol} \% \mathrm{Bi}_{2} \mathrm{O}_{3}$. Beside, the Alumina rich region indicates a first liquid at $1070^{\circ} \mathrm{C}$. This temperature is 
very similar to the temperature range for liquid phases detection in compositions 4, 5, 6 and 7 in figures 4 and 5. The $\mathrm{Bi}_{2} \mathrm{O}_{3}-\mathrm{SiO}_{2}$ system is different as it contains the $\mathrm{Bi}_{4} \mathrm{Si}_{3} \mathrm{O}_{12}$ phase, which is different from the $\mathrm{Bi}_{12} \mathrm{Si}_{0.87} \mathrm{O}_{20}$ detected in samples 6 and 7 at $1000^{\circ} \mathrm{C}$ and $1100^{\circ} \mathrm{C}$. But the first liquid appears at the $1020^{\circ} \mathrm{C}$ temperature, close to the liquid temperature of our samples.

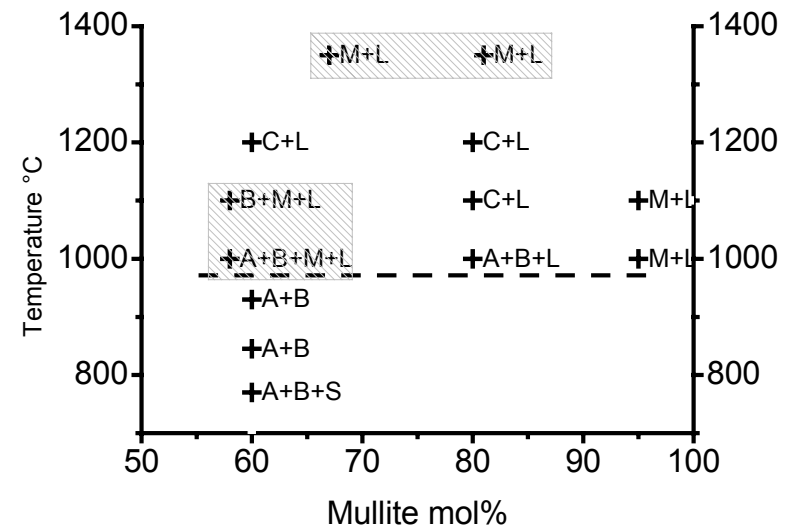

Fig. 8: Phase diagram $\mathrm{Bi}_{2} \mathrm{O}_{3}-$ mullite; $\mathrm{B}$ - Bismuth Silicon Oxide; A - Aluminum Bismuth Oxide; $\mathrm{S}$ Sillenite; M - Mullite; C - Corundum

A tentative pseudo-binary diagram mullite- $\mathrm{Bi}_{2} \mathrm{O}_{3}$ is presented in figure 8 . The liquid limit is slightly below $1000^{\circ} \mathrm{C}$, for a large $\mathrm{Bi}_{2} \mathrm{O}_{3}$ content. Above approximately $1100^{\circ} \mathrm{C}$, corundum coexists with the liquid and this behavior is similarly observed in the $\mathrm{Al}_{2} \mathrm{O}_{3}-\mathrm{Bi}_{2} \mathrm{O}_{3}$ system above $1070^{\circ} \mathrm{C}$. For compositions outside the mullite $-\mathrm{Bi}_{2} \mathrm{O}_{3}$ axis (samples 2,3 and 4) the crystallized phases are different (composition plotted in gray shade in figure 7), but the liquid temperature is not different.

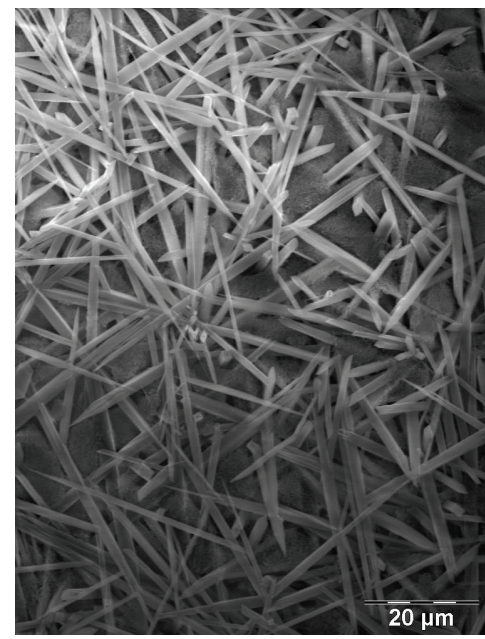

Fig. 9: Microstructure at the Muscovite-kaolinite interface when $1 \mathrm{~mol} \%$ of $\mathrm{Bi}_{2} \mathrm{O}_{3}$ is added.

\section{Mullite formation in phyllosilicate mixes}

The effect of $\mathrm{Bi}_{2} \mathrm{O}_{3}$ addition on phase formation and microstructural evolution of mullite ceramics from kaolinite-muscovite minerals was investigated. In this material, $\mathrm{Bi}_{2} \mathrm{O}_{3}$ was added as a thin coating onto muscovite flakes, before the muscovite-kaolinite mixing, using a bismuth nitrate aqueous solution. The $\mathrm{Bi}_{2} \mathrm{O}_{3}$ to mullite ratio in sintered material is close to $5 \mathrm{~mol} \%$. But, it can be supposed that a local high concentration of bismuth oxide exist at crystallite interfaces. In these restricted zones, local interactions could be described by the behavior of compounds containing high concentration of $\mathrm{Bi}_{2} \mathrm{O}_{3}$ in the pseudo binary diagram of figure 8 .

With muscovite-kaolinite compound, SEM observations point to the acceleration of mullitization with the presence of $\mathrm{Bi}_{2} \mathrm{O}_{3}$. In figure 9, the surface of muscovite sintered at $1250^{\circ} \mathrm{C}$ for 1 hour holding time shows large anisotropic mullite grains, which average length attains $30 \mu \mathrm{m}$.

In this material, whereas the probable occurrence of crystallized compounds of $\mathrm{Bi}_{2} \mathrm{O}_{3}$ with alumina and silica, no reactions are found by $\mathrm{x}$-ray in sintered materials. Also, $\mathrm{Bi}_{2} \mathrm{O}_{3}$ was not detected even for samples with high $\mathrm{Bi}_{2} \mathrm{O}_{3}$ addition. The most interesting point is the significant mullite crystallization and growth at low temperature. Simultaneously, $\mathrm{Bi}_{2} \mathrm{O}_{3}$ highly favors the sintering densification and this effect is attributed to the specific role of a local low-viscosity liquid phase in the systems.

\section{Conclusion}

Mullite doped by bismuth was synthesized by a sol-gel process. Effect of $\mathrm{Bi}_{2} \mathrm{O}_{3}$ on phase formation and microstructural evolution of mullite ceramics were investigated by different methods. They all point to the important role of $\mathrm{Bi}_{2} \mathrm{O}_{3}$ on mullite formation. At weak bismuth content, mullite is crystallized in all mixes below $1000^{\circ} \mathrm{C}$ and above. When bismuth content exceed about $10 \mathrm{~mol} \%$, mullite is no longer crystallized and both bismuth silicon oxide, aluminum bismuth oxide, sillenite and corundum are present in variable contents. Mullite is detected in sample with high bismuth content at temperature exceeding $1200^{\circ} \mathrm{C}$ and for compositions beside the mullite $\mathrm{Bi}_{2} \mathrm{O}_{3}$ axis. For all studied compositions, a liquid phase appears at temperature in the $950-1000^{\circ} \mathrm{C}$ temperature range.

In silico-aluminate compositions, the occurrence of a liquid when $\mathrm{Bi}_{2} \mathrm{O}_{3}$ is added highly favors the mullite growth at temperature below $1200^{\circ} \mathrm{C}$. It is favored by local concentrations at interfaces of a transient liquid phase, which enhance the mobility of species.

\section{Acknowledgements}

The authors would like to express their gratitude towards the European Community (the European Social Funds) and the Limousin Region for their financial support of the present work. 


\section{References}

1. M. Mizuno, H. Saito: "Preparation of Highly Pure Fine Mullite Powder", J.Am. Ceram. Soc., 72 [3] 37782, (1989)

2. L.Saadi, R.Moussa: "Synthesis of Mullite Precursors in Molten Salts. Influence of the Molten Alkali Nitrate and Additives", J. Eu. Ceram. Soc., 19, (1999)

3. L.B.Kong, T.S. Zhang: "Some main group oxides mullite phase formation and microstrukture evolution", Journal of Alloys and Compounds, 359, (2003)

4. S. Hong, G.Messing: "Anisotropic Grain Growth in Boria doped Diphasic Mullite Gels", J. Eu. Ceram. Soc., 19, (1999)

5. D.Amutharani, F.D. Gnanam: "Low temperature pressureless sintering of sol-gel derived mullite", Material Science and Enginnering, A264, 254-261, (1999)

6. Chen Y.F., Vilminot S., "Characterization of sol gel mullite powders", Materials Research Bulletin 30, 291298, (1995)

7. Janackovic D., Janackovic V., "Synthesis of mullite nanostrucured spherical powder by ultrasonic spray pyrolysis", NanoStructured Materials 10, 341-348, (1998)

8. Patil M.M., "Synthesis of bismuth oxide nanoparticles at $100^{\circ} \mathrm{C}$ ", Mater. Letters 59, 2523252,(2005)

9. Chakraborty A.K., "Aluminosilikate formation in various mixtures of tetra ethyl ortosilicate (TEOS) and aluminum nitrate (ANN)", Thermochimica Acta 427, 109-116 (2005)

10. Speranskaya E.I., Skorikov V.M., "System $\mathrm{Al}_{2} \mathrm{O}_{3}-$ $\mathrm{Bi}_{2} \mathrm{O}_{3}$ ", Inorg. Mater., 6 [7] 1201-1202, (1970)

11. MacDowell J.F., Beall G.H., "System $\mathrm{SiO}_{2}-\mathrm{Al}_{2} \mathrm{O}_{3}$ ", J.Am. Ceram. Soc., 52 [1] 17-25, (1969)

12. Kargin Yu. F., Zhereb V.P., "System $\mathrm{Bi}_{2} \mathrm{O}_{3}-\mathrm{SiO}_{2}$ ", Russ. J; Inorg. Cehm., 36 [10] 1466-1469, (1991)

13. Chen Z., Zhang L., "Novel Method og adding seeds for preparation of mullite", Jour. of Mat. Proc. Tech. 166, 183-187, (2005)

14. Akshoy K., "DTA study of preheated kaolinite in the mullite formation region", Thermochinica Acta 398, 203-209, (2003)

15. V. Fruth, A.Ianculesca: "Synthesis, structure and properties of doped $\mathrm{Bi}_{2} \mathrm{O}_{3}$ ", J. Eu. Ceram. Soc., (2006) 